\title{
Implementation of an In-House Quantitative Real-Time PCR for Determination of HIV Viral Load in Kinshasa
}

\author{
Erick Ntambwe Kamangu ${ }^{*}$, Adawaye Chatte ${ }^{2}$, Raphael Boreux ${ }^{3}$, Richard Lunganza Kalala1, \\ Georges Lelo Mvumbi ${ }^{1}$, Patrick Demol ${ }^{3}$, Dolores Vaira ${ }^{4}$, Pierre Marie Hayette ${ }^{3}$ \\ ${ }^{1}$ Unit of Molecular Biology, Department of Science Basis, Faculty of Medicine, University of Kinshasa (UNIKIN), \\ Kinshasa, Democratic Republic of Congo (DRC) \\ ${ }^{2}$ University Institute of Science and Technology of Abeche, Abeche, Chad \\ ${ }^{3}$ Laboratoryof Clinical Microbiology, University Hospital-University of Liège, Liege, Belgium \\ ${ }^{4}$ AIDS Reference Laboratory (LRS), University Hospital-University of Liège, Liege, Belgium \\ Email: ${ }^{*}$ erick.kamangu@unikin.ac.cd
}

Received 2 August 2014; revised 18 September 2014; accepted 20 October 2014

Copyright (C) 2014 by authors and OALib.

This work is licensed under the Creative Commons Attribution International License (CC BY). http://creativecommons.org/licenses/by/4.0/

(c) (i) Open Access

\begin{abstract}
Background: Measurement of Viral Load (VL) is the most reliable mean for evaluating virological monitoring of the Human Immunodeficiency Virus (HIV) infection. It allows determination of the amount of virus present in a given volume. Due to the constraints of costs, the VL is not often requested for patient's follow-up in countries with limited resources. Hence the objective of this study is to implement an in-house Quantitative Real-Time PCR to assess the VL of HIV infected patients in Kinshasa. Methods: One hundred and fifty five patients positive for HIV type 1, naive of Antiretroviral Therapy (ART) and eligible for treatment were included in the study. Five milliliter of blood was collected in a tube with anticoagulant. One milliliter of plasma was sent to the laboratory for analysis. After RNA extraction, a Quantitative Real time PCR was performed on a portion of the region of the Long Terminal Repeat (LTR) of the virus. Results: 0 Of 155 samples received for determination of VL by Quantitative Real-Time PCR, 153 were successfully amplified according to the protocol. The median VL was 301052.97 copies/ml or $5.48 \log _{10}$. Conclusions: The results of VL were used to assess the feasibility of the Real-Time Quantitative PCR. It turns a simple, reliable and less expensive alternative for the diagnosis and virological monitoring of HIV patients under ART.
\end{abstract}

\section{Keywords}

Real Time PCR, Viral Load, Kinshasa, HIV

\footnotetext{
${ }^{*}$ Corresponding author.
}

How to cite this paper: Kamangu, E.N., Chatte, A., Boreux, R., Kalala, R.L., Mvumbi, G.L., Demol, P., Vaira, D. and Hayette, P.M. (2014) Implementation of an In-House Quantitative Real-Time PCR for Determination of HIV Viral Load in Kinshasa. Open Access Library Journal, 1: e855. http://dx.doi.org/10.4236/oalib.1100855 


\section{Introduction}

Measurement of plasma Viral Load (VL) is the most reliable way to assess virological monitoring infection with Human Immunodeficiency Virus (HIV). It is frequently used in clinical setting for diagnosis and virological monitoring of patients on Antiretrovirals (ARVs) [1]. It is also used to evaluate the effect of the ARV treatment. It estimates the amount of virus in a given volume. It also determines the success or failure of Antiretroviral Treatment (ART) whose main objective is for the suppression of viral replication [2] [3]. Studies have shown that sites with VL monitoring have lower mortality and morbidity rates and better justification of changing to better lines of therapy than those using only CD4 T cells count monitoring [2] [3].

Due to cost constraints, the VL is not frequently requested for patients monitoring in countries with limited resources [3] [4]. The recommendations of the World Health Organization (WHO) for countries with limited resources, do not emphasize on the VL for patient monitoring; they advocate the use of clinical data (WHO clinical stage) first, and measure the value of CD4 T cells when available [2]. Clinical evaluation or CD4 count alone is not sufficient to establish proper monitoring of patients on ART [2]-[4]. This is one of the causes of poor evaluation of treatment failure [5] and the calamitous treatment monitoring of patients in countries with limited resources [2]-[5].

The VL is an important tool for monitoring patients. It is therefore important to find a more affordable alternative to the evaluation of the VL. Hence the objective of this study is to implement an in-house Quantitative Real-Time PCR to assess the VL of HIV infected patients in Kinshasa.

\section{Methodology}

\subsection{Framework}

This study was conducted as a cross-sectional study in collaboration with different Centers for Treatment and Supported People Living with HIV (PLHIV) in the city of Kinshasa [6]. It was conducted from July 2013 to February 2014.

\subsection{Patients}

One hundred and fifty five (155) patients diagnosed serologically positive for HIV Type 1 and naive of Antiretroviral Treatment (ART) were included in the study. Patients were diagnosed positive for HIV in the respective centers of origin according to the protocol of the National Program for the Fight against HIV/AIDS and Sexually Transmitted Infections [7]. These were all patients eligible for ART in their centers as recommended by the World Health Organization (WHO) [2]. Participation was voluntary for patients in this study. All participants signed an informed consent before the start of sampling.

\subsection{Blood Sampling}

Five milliliter $(5 \mathrm{ml})$ of blood were collected in a tube with EDTA anticoagulant from the vein in the crook of the elbow. The collected blood was centrifuged at $1000 \mathrm{~g}$ for 10 minutes to obtain a clear separation into 3 phases. One milliliter of plasma (supernatant) was transferred into a microtube previously labeled and stored at $-20^{\circ} \mathrm{C}$ before being transported to the laboratory of Molecular Biology, Faculty of Medicine for analysis.

\subsection{Extraction and Amplification of RNA}

The RNA extraction was made from $140 \mu \mathrm{l}$ of plasma and $10 \mathrm{ul}$ of the internal extraction control (RNA-050.vs1 Diagenode) using the QIAamp RNA Mini Kit QIAGEN ${ }^{\circledR}$ kit for RNA extraction Laboratory of Molecular Biology [8]. The extracted samples were stored at $-20^{\circ} \mathrm{C}$ until use. Control has its primers and probes included in the kit (DIA-EIC/RNA(Cy5)-050 Diagenode) that give it a Ct value of \pm 28.5 for 10,000 TCID 50/ml.

After extraction, a Multiplex Quantitative Real Time PCR was carried out for determining the amount of proviral HIV DNA in samples (Table 1 and Table 2) according to protocols previously described [9]-[11] [12]. 
Table 1. Primes and probes for the Real-Time PCR.

\begin{tabular}{|c|c|c|c|}
\hline Primers & \multicolumn{3}{|c|}{ Sequences } \\
\hline HIV1MGForward & \multicolumn{3}{|c|}{ 5'-GCCTCAATAAAGCTTGCCTTGA-3' } \\
\hline HIV1MGReverse & \multicolumn{3}{|c|}{ 5'-GGCGCCACTGCTAGAGATTTT-3' } \\
\hline HIV1MGProbe FAM & \multicolumn{3}{|c|}{ 5’-AAGTAGTGTGTGCCCGTCTGTTRTKTGACT-3’ BHQ1 } \\
\hline \multicolumn{4}{|c|}{ Table 2. Cycle of PCR/Taq Man one step sur ABI ${ }^{\circledR} 7500$ fast. } \\
\hline Temperature $\left({ }^{\circ} \mathrm{C}\right)$ & Time (min: sec) & Steps & Amplification \\
\hline 50 & 30: 00 & Transcription Inverse & \\
\hline 95 & 10: 00 & Activation de l'Enzyme & \\
\hline 95 & $0: 15$ & Dénaturation par cycle & \\
\hline 60 & 1: 00 & Hybridation par cycle & \\
\hline
\end{tabular}

Targeted viral amplification region is part of the Long Terminal Repeat (LTR), which is the region more or less constant and preserved the genome of HIV type 1 [9] [13]. The calibration curve was plotted with standard controls. The standards used to graph the curve are commercial plasmas previously quantified from $10^{2}$ to $10^{7}$ by increments of a logarithm of 10 (AcroMetrix Control Panel \# 94-2013). The inclination is acceptable for curve included between -3.40 and -3.10 in accordance with the protocol applicable thermocycler 7500 Fast RealTime PCR System from Applied Biosystems (ABS) [12], and between -3.60 and -2.90 according to the procedure of viral quantification Biocentric marketed by [14].

\section{Results}

\subsection{Serology}

A total of 155 samples of different HIV-infected patients, treatment-naive and eligible for ARVs treatment were received for determination of Viral Load (VL) by a Quantitative Real-Time PCR between July 2013 and February 2014. All samples were previously diagnosed HIV positive with Rapid Diagnostic Tests (RDT) in the respective centers.

\subsection{Sex and Age}

Of the 155 patients, we have 63 men and 92 women, a sex ratio of 1.46:1. The age group most represented is that of 26 to 35 years with 44 patients (28.39\%) followed by that of 46 - 55 years (25.80\%) and 18 - 25 years (20.65\%) (Table 3).

\subsection{Viral Load}

One hundred and fifty three (153) samples were successfully amplified according to the protocol, or $98.71 \%$ of amplification. The median and mean values of VL are respectively 301,052 copies $/ \mathrm{ml}$ or $5.48 \log _{10} \mathrm{copies} / \mathrm{ml}$ and 2,940,665 copies/ml or $6.47 \log _{10}$ copies/ml (Table 4). The extreme values of VL are 0 and 88,849,472 copies $/ \mathrm{ml}\left(0\right.$ and $\left.7.95 \log _{10}\right)$, respectively for the extreme lower and higher values (Table 4).

\section{Discussion}

This aim of the study was to implement and evaluate the feasibility of an in-house Quantitative Real-Time PCR for assessment of plasma HIV Viral Load. One hundred fifty-five (155) plasma samples were amplified to determine the amount of viral RNA. All samples were previously tested for HIV by Rapid Diagnostic Tests (RDT) in the respective centers of origin.

One hundred fifty-three (153) of 155 samples were successfully amplified by following the in-house protocol. This gives us a success rate of $98.71 \%$ for the estimation of the VL in HIV positive patients in Kinshasa. The 
Table 3. Age group of patients.

\begin{tabular}{cc}
\hline Age groups & Frequency (\%) \\
\hline $\mathbf{1 8}-\mathbf{2 5}$ & $32(20.65 \%)$ \\
$\mathbf{2 6}-\mathbf{3 5}$ & $44(28.39 \%)$ \\
$\mathbf{3 6}-\mathbf{4 5}$ & $40(25.80 \%)$ \\
$\mathbf{4 6}-\mathbf{5 5}$ & $26(16.77 \%)$ \\
$\mathbf{5 6}-\mathbf{6 5}$ & $13(8.39 \%)$ \\
Total & $\mathbf{1 5 5 ( 1 0 0 \% )}$ \\
\hline
\end{tabular}

Table 4. Results of Viral Load PCR on J0.

\begin{tabular}{ccc}
\hline & \multicolumn{2}{c}{ Values } \\
\cline { 2 - 3 } & Copies/ml & $\log _{10}$ \\
\hline Maximum VL & $88,849,472$ & 7.95 \\
Minimum VL & 0 & - \\
Median VL & 301,052 & 5.48 \\
Mean VL & $2,940,665$ & 6.47 \\
\hline
\end{tabular}

technique is therefore reliable with a detection rate higher than $95 \%$. Of the two non-reactive samples, after investigation, one patient affirmed that he have been followed prior to another facility for more than a year where he used to pay for the ARVs. This would explain the change in treatment center without informing them of the transfer and an undetectable VL if properly taking his treatment. The second non-reactive sample could be a different type of HIV because this technic if specific for HIV type 1 group M [11] [15].

With a detection limit of less than 100 copies/ml, this technique is a sensitive and reliable tool for evaluation of VL [16]. One major advantage of this technique is that it can be reproduced on any other real-time thermal cycler that has been previously validated. It is not limited to one brand or model of machine. It is a versatile open technique that can be used on all platforms. The PCR can be run on any Real-Time thermal cycler that can observe the protocols of temperature and time. The low-tech, and the relative simplicity of the technique make it a reliable and affordable method of evaluation in countries with limited resources. However, although little laborious, it requires appropriate facilities and well equipped for each handling step, and micropipettes calibrated regularly.

Moreover, it can be adapted to the genetic diversity of the country especially as primers and probes can be adjusted as necessitated. It is flexible and can be shaped to meet the need of the genetic diversity of HIV in Africa.

The other advantage of this in-house technique is the cost of the examination. Compared to other commercial kits, the commercial version of this technique (Biocentric) is the least expensive method for the evaluation of VL for the PLHIV [9] [15]. It provides a commercial reagent price of less than 10 American dollars (USD) per test. This is cheaper than all other commercial tests on the market [9] [15] that approximate 50.00 USD in laboratories performing VL in Kinshasa [6].

\section{Conclusion}

The results of Viral Loads allowed us to assess the feasibility of the Quantitative Real-Time PCR. This method is a simple, reliable and less expensive alternative mean for the diagnosis and virological monitoring of HIV patients on ARVs. The use of validated real-time PCR open systems technology should be recommended for monitoring patients in countries with limited resources.

\section{Acknowledgements}

The authors thank the managers and staff of laboratories centers that participated in this study and the staff of the LRS-Liège for learning new techniques. 


\section{Conflict of Interest}

The authors declare that there is no conflict of interest.

\section{References}

[1] World Health Organization. Towards Universal Access by 2010. How WHO Is Working with Countries to Scale-Up HIV Prevention, Treatment, Care and Support. World Health Organization, Geneva, 2006. www.who.int/hiv/universalaccess2010/en

[2] (2010) World Health Organization. Antiretroviral Therapy for HIV Infection in Adults and Adolescents: Recommendations for a Public Health Approach (2010 Revision). World Health Organization, Geneva. www.who.int/publications/2010/9789241599764_eng.pdf

[3] (2012) Médecins Sans Frontières. Undetectable-How Viral Load Monitoring Can Improve HIV Treatment in Developing Countries. Médecins Sans Frontières, Geneva. www.msfaccess.org/content/undetectable-how-viral-load-monitoring-can-improve-hiv-treatment-developing-countries

[4] Boyer, S., March, L., Kouanfack, C., Laborde-Balen, G., Marino, P., Fobang, A.A., Mpoudi-Ngole, E., Koulla-Shiro, S., Delaporte, E., Carrieri, M.P., Spire, B., Laurent, C.C. and Moatti, J.P., on Behalf of the Stratall ANRS 12110/ ESTHER Study Group (2013) Monitoring of HIV Viral Load, CD4 Cell Count, and Clinical Assessment Versus Clinical Monitoring Alone for Antiretroviral Therapy in Low-Resource Settings (Stratall ANRS 12110/ESTHER): A CostEffectiveness Analysis. The Lancet Infectious Diseases, 13, 577-586. http://dx.doi.org/10.1016/S1473-3099(13)70073-2

[5] (2010) Integrated Regional Information Networks (IRIN) Afrique: L’échec thérapeutique trop souvent mal détecté. www.irinnews.org/fr

[6] Kamangu, N.E., Kalala, N.H. and Mesia, K.G. (2012) Profile of Antiretroviral Treatment Centers in Kinshasa, Democratic Republic of Congo [Poster 388]. Proceedings of the 1st International African Society of Laboratory Medicine (ASLM) Conference, 1-7 December 2012, Cape Town, 377.

[7] (2008) Programme National de Lutte contre le VIH/SIDA et les Infections Sexuellement Transmissibles (PNLS), Ministère de la Santé Publique, République Démocratique du Congo. Guide National de traitement de l'infection à VIH par les ARV chez l'adolescent et l'adulte.

[8] (2010) QIAGEN: QIAamp ${ }^{\circledR}$ RNA Mini and Blood Mini Handbook. 3rd Edition, 27-29.

[9] Rouet, F., Chaix, M.L., Nerrienet, E., Ngo-Giang-Huong, N., Plantier, J.C., Burgard, M., Peeters, M., Damond, F., Koumavi, E.D., Msellati, P., Ferradini, L., Rukobo, S., Maréchal, V., Schvachsa, N., Wakrim, L., Rafalimanana, C., Rakotoambibiba, B., Viard, J.P., Seigneurin, J.M. and Rouzioux, C., for the Agence Nationale de Recherchessur le SIDA AC11/AC12 Working Groups (2007) Impact of HIV-1 Genetic Diversity on Plasma HIV-1 RNA Quantification: Usefulness of the Agence Nationale de Recherches sur le SIDA Second-Generation Long Terminal Repeat-Based Real-Time Reverse Transcriptase Polymerase Chain Reaction Test. Journal of Acquired Immune Deficiency Syndrome, 45, 380-388. http://dx.doi.org/10.1097/QAI.0b013e3180640cf5

[10] Steegen, K., Luchters, S.S., De Cabooter, N., Reynaerts, J., Mandaliya, K., Plum, J., Jaoko, W., Verhofstede, C. and Temmerman, M. (2007) Evaluation of Two Commercially Available Alternatives for HIV-1 Viral Load Testing in Resource-Limited Settings. Journal of Virological Methods, 146, 178-187. http://dx.doi.org/10.1016/j.jviromet.2007.06.019

[11] Rouet, F., Foulongne, V., Viljoen, J., Steegen, K., Becquart, P., Valéa, D., Danaviah, S., Segondy, M., Verhofstede, C., Van de Perre, P., for the WHO/ANRS 1289 Kesho Bora Study Group (2010) Comparison of the Generic HIV Viral Load $^{\circledR}$ Assay with Amplicor ${ }^{\mathrm{TM}}$ HIV-1 Monitoring v1.5 and Nuclisens HIV-1 EasyQ ${ }^{\circledR}$ v1.2 Techniques for Plasma HIV-1 RNA Quantification of Non-B Subtypes: The Kesho Bora Preparatory Study. Journal of Virological Methods, 163, 253-257. http://dx.doi.org/10.1016/j.jviromet.2009.10.005

[12] Applied Biosystems. www.appliedbiosystems.com

[13] Drosten, C., Panning, M., Drexler, J.F., Hänsel, F., Pedrosoc, C., Yeats, J., de Souza Luna, L.K., Samuel, M., Liedigk B., Lippert, U., Stürmer, M., Doerr, H.W., Brites, C. and Preiser ,W. (2006) Ultrasensitive Monitoring of HIV-1 Viral Load by a Low-Cost Real-Time Reverse Transcription-PCR Assay with Internal Control for 5' Long Terminal Repeat Domain. Clinical Chemistry, 52, 1258-1266. http://dx.doi.org/10.1373/clinchem.2006.066498

[14] Biocentric. www.biocentric.com/

[15] Rouet, F. and Rouzioux, C. (2007) The Measurement of HIV-1 Viral Load in Resource-Limited Settings: How and Where? Clinical Laboratory, 53, 135-148.

[16] Kamangu, E., Chatté, A., Boreux, R., Susin, F., Kalala, R., Mvumbi, G., Vaira, D. and Hayette, M.P. (2014) Comparaison d’une PCR Quantitative Maison en Temps Réel et du COBAS/Ampliprep TaqMan de Roche pour la détermination de la Charge Virale des Variantes du VIH Type 1 non-B. 